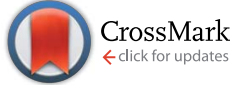

Cite this: J. Mater. Chem. A, 2016, 4, 12241

Received 29th June 2016

Accepted 7th July 2016

DOI: $10.1039 / c 6 t a 05472 b$

www.rsc.org/MaterialsA

\title{
Guanidinium nonaflate as a solid-state proton conductor $\dagger$
}

\author{
Xiaoli Chen, ${ }^{a}$ Haolin Tang, ${ }^{\star a}$ Tristan Putzeys, ${ }^{b}$ Jeroen Sniekers, ${ }^{c}$ \\ Michael Wübbenhorst, ${ }^{\mathrm{b}}$ Koen Binnemans, ${ }^{\mathrm{c}}$ Jan Fransaer, ${ }^{\mathrm{d}}$ Dirk E. De Vos, \\ Qingfeng $\mathrm{Li}^{f}$ and Jiangshui Luo*def
}

\begin{abstract}
Protic organic ionic plastic crystals (POIPCs) are a type of novel solid-state proton conductors. In this work, guanidinium nonaflate ([Gdm-H][NfO]) is reported to be a model POIPC. Its structure-property relationship has been investigated comprehensively. Infrared analysis of [Gdm-H][NfO] and its deuterated analogue [Gdm-D][NfO] confirms the complete formation of the protic salts. The cations in as-prepared [Gdm-D] $[\mathrm{NfO}]$ are estimated to consist of $\left[\mathrm{C}\left(\mathrm{ND}_{2}\right)_{2}(\mathrm{NHD})\right]^{+}$and $\left[\mathrm{C}\left(\mathrm{ND}_{2}\right)_{3}\right]^{+}$with a molar ratio of around $1: 1$. The deuteration also proves that each guanidinium cation has six displaceable protons. Thermogravimetric analysis demonstrates that [Gdm-H][NfO] exhibits superior thermal stability in both nitrogen and air atmospheres. Isothermogravimetric analysis reveals its negligible vapor pressure with an estimated high enthalpy of vaporization (120.9 $\mathrm{kJ} \mathrm{mol}^{-1}$ ). Differential scanning calorimetry measurements of [Gdm- $\mathrm{H}$ ] [NfO] show four evident endothermic peaks prior to its melting transition at $186.2^{\circ} \mathrm{C}$ with a low entropy of melting (17.70 $\left.\mathrm{J} \mathrm{K}^{-1} \mathrm{~mol}^{-1}\right)$. Shortly before the onset temperature of melting transition $\left(186.2^{\circ} \mathrm{C}\right)$, partial melting (partial liquefaction) was observed via polarized optical microscopy in the temperature region of $176-186{ }^{\circ} \mathrm{C}$ while the reason for partial melting of ionic plastic crystals is not clear yet. Variable-temperature powder X-ray diffraction tests confirm the related solid-solid phase transitions and demonstrate that [Gdm-H][NfO] exhibits short-range disorder and long-range positional order in the plastic crystalline phases. Dielectric spectroscopy measurements show that its ionic conductivity reaches $2.1 \times 10^{-3} \mathrm{~S} \mathrm{~cm}^{-1}$ at $185^{\circ} \mathrm{C}$. The proton conduction in the plastic crystalline phases of [Gdm-H][NfO] is assumed to happen via the vehicle mechanism. In the molten state, the proton conduction follows a combination of the vehicle mechanism and the Grotthuss mechanism (structural diffusion). In summary, due to their exceptional physicochemical properties, POIPCs like [Gdm-H][NfO] are promising electrolyte materials for high temperature $\left(100-200{ }^{\circ} \mathrm{C}\right)$ proton exchange membrane fuel cells. In addition, POIPC-based solid-state proton conductors are also expected to find applications in sensors and other electrochemical devices.
\end{abstract}

\section{Introduction}

${ }^{a}$ State Key Laboratory of Advanced Technology for Materials Synthesis and Processing, Wuhan University of Technology, Wuhan 430070, P. R. China. E-mail: thln@whut.edu. cn

${ }^{b}$ Department of Physics and Astronomy, KU Leuven, Leuven 3001, Belgium

'Department of Chemistry, KU Leuven, Leuven 3001, Belgium

${ }^{d}$ Department of Materials Engineering, $K U$ Leuven, Leuven 3001, Belgium. E-mail: jiangshui.luo@kuleuven.be

${ }^{e}$ Centre for Surface Chemistry and Catalysis, $K U$ Leuven, Leuven 3001, Belgium ${ }^{f}$ Department of Energy Conversion and Storage, Technical University of Denmark, Kgs. Lyngby 2800, Denmark

$\dagger$ Electronic supplementary information (ESI) available: FTIR spectrum of guanidine carbonate; isothermal gravimetric analysis at five discrete temperatures; DSC traces at 10 and $20{ }^{\circ} \mathrm{C} \mathrm{min}^{-1}$, respectively; DSC curves of $[\mathrm{Gdm}-\mathrm{H}][\mathrm{NfO}]$ at different heating/cooling rates showing the phase transition of phase III $\rightarrow$ phase II and the corresponding limiting temperature hysteresis; images of POM observations; Nyquist plots at various temperatures. See DOI: $10.1039 / \mathrm{c} 6 \mathrm{ta} 05472 \mathrm{~b}$
Hydrogen fuel is a promising candidate for replacing fossil fuels. Proton exchange membrane fuel cells (PEMFCs) are promising electrochemical devices for the direct conversion of hydrogen energy into electric energy. ${ }^{1}$ Commercial PEMFCs mainly employ perfluorinated sulfonic acid membranes (e.g. Nafion $\left.{ }^{\circledR}\right)$. However, these fuel cells still have several disadvantages, including high cost, low reliability and dependence on hydration of inlet gases. Despite extensive research, the proton exchange membrane (PEM), which is a critical component of PEMFCs and which is in essence a proton conductor, still faces multiple challenges. On the other hand, operating PEMFCs at high temperatures (typically $100-200{ }^{\circ} \mathrm{C}$ ) can offer some benefits such as improved electrode kinetics, simpler water and heat management, and better tolerance to fuel impurities, leading to higher overall energy conversion efficiencies. Therefore, high 
temperature PEMFCs have attracted a lot of attention from the research community in recent years. ${ }^{2}$

State-of-the-art high temperature PEMFCs involve liquid electrolytes, such as $\mathrm{H}_{3} \mathrm{PO}_{4}$ and ionic liquids. ${ }^{2-4}$ However, they have potential drawbacks such as leaching of liquids, accelerated degradation of fuel cell components due to the use of acid doped systems, and long-term instability. Hence, solid-state proton conductors are preferred due to their advantages in terms of fabrication, maintenance and durability of devices. ${ }^{5}$ Haile et al. reported solid acids (e.g. $\mathrm{CsHSO}_{4}$ ) as fuel cell electrolytes. $^{5 \boldsymbol{b}, \boldsymbol{c}}$ The practical application of these solid acid electrolytes suffers from the narrow temperature window of the superprotonic phase, poor thermal stability, requirement of humidity for stabilization, and difficulties for the preparation of thin films from inorganic rigid particles. ${ }^{5 b, c}$

Recently, we have demonstrated that protic organic ionic plastic crystals (POIPCs), which are solid protic organic salts formed by proton transfer from a Brønsted acid to a Brønsted base, are promising solid-state proton conductors for high temperature PEMFCs. ${ }^{5 a}$

Like molecular plastic crystals $^{6}$ and other organic ionic plastic crystals, ${ }^{7-11}$ POIPCs exhibit mesophases (i.e. states of matter intermediate between liquid and solid), which are characterized by various forms of disorder due to one or more solid-solid phase transitions below the melting point and therefore exhibit soft, plastic mechanical properties and notable ionic (protonic) conductivity. ${ }^{5 a}$ The unique mechanical and transport properties of POIPCs originate from their longrange positional order but short-range orientational or rotational disorder of cations and/or anions in the crystal, allowing for high intrinsic proton conductivity in the solid state. Meanwhile, they exhibit other desirable properties such as nonflammability, negligible volatility, high thermal stability, and wide electrochemical windows, favoring their long-term stability when applied in high temperature PEMFCs under harsh working conditions (e.g. high temperature, flowing gases, and oxidative and reductive environment at the anode and the cathode, respectively).

Nevertheless, the limited reported POIPCs ${ }^{5 a, 11,12}$ as solid-state proton conductors suffer from shortcomings such as (i) insufficient proton conductivity $\left(\right.$ e.g. $2.62 \times 10^{-6} \mathrm{~S} \mathrm{~cm}^{-1}$ at $165^{\circ} \mathrm{C}$ for<smiles>N=C(N)[I+]</smiles>
guanidinium nonaflate $([\mathrm{Gdm}-\mathrm{H}][\mathrm{NfO}])$<smiles>O=[N+]([O-])C([PH2+])=[N+]([O-])[O-]</smiles>
deuterated guanidinium nonaflate ([Gdm-D][NfO])

Fig. 1 Chemical structures of guanidinium nonaflate [Gdm-H][NfO] and its deuterated form [Gdm-D][NfO]. 1,2,4-triazolium nonaflate ${ }^{5 a}$ ) or (ii) relatively narrow plastic crystalline phase (e.g. $174-188{ }^{\circ} \mathrm{C}$ for imidazolium methanesulfonate ${ }^{11}$ and $115-160{ }^{\circ} \mathrm{C}$ for guanidinium triflate ${ }^{12}$ as pure POIPCs).

Herein, we report guanidinium nonaflate $[\mathrm{Gdm}-\mathrm{H}][\mathrm{NfO}]$ (Fig. 1) as a new POIPC with significant ionic conductivity in the higher-temperature plastic crystalline phase as well as high thermal stability and negligible volatility. Its deuterated analogue [Gdm-D][NfO] (Fig. 1) was also prepared and investigated.

\section{Experimental}

\section{Sample preparation}

[Gdm-H][NfO] was prepared by combination of equimolar amounts of nonaflic acid $\left(n-\mathrm{C}_{4} \mathrm{~F}_{9} \mathrm{SO}_{3} \mathrm{H}, \mathrm{TCI}, 98 \%\right)$ and carbonate salt of guanidine $\left(\mathrm{NH}_{2} \mathrm{C}(=\mathrm{NH}) \mathrm{NH}_{2} \cdot \frac{1}{2} \mathrm{H}_{2} \mathrm{CO}_{3}\right.$, Alfa Aesar, 98\%). The nonaflic acid was firstly diluted and then slowly added to a solution of the carbonate salt of guanidine under magnetic stirring in an ice bath for $3 \mathrm{~h}$. The mixture was further heated at $120^{\circ} \mathrm{C}$ in a silicon oil bath for $24 \mathrm{~h}$ to promote the neutralization reaction. Bubbles of carbon dioxide were released during the reaction. After the reaction, the compound was purified by heating it on a Schlenk line in vacuo at $190^{\circ} \mathrm{C}$ for $18 \mathrm{~h}$ to remove water and the excess base or acid (if any), resulting in a dry crystalline powder. The purified samples were stored in an argon-filled glove box prior to further characterizations.

Deuterated guanidinium nonaflate [Gdm-D][NfO] (Fig. 1) was prepared as follows: $10.0 \mathrm{~g}$ of $\mathrm{D}_{2} \mathrm{O}(99.9$ at.\% $\mathrm{D}$, InnoChem, Beijing) was used to dissolve $2.0 \mathrm{~g}$ of [Gdm-H][NfO] $(n([\mathrm{Gdm}-\mathrm{H}]$ $\left.[\mathrm{NfO}]): n\left(\mathrm{D}_{2} \mathrm{O}\right)=1: 90\right)$ in a well-sealed flask with magnetic stirring for $12 \mathrm{~h}$. The solution was then stored at room temperature for 1 week. The deuterated sample was thereafter dried at $55{ }^{\circ} \mathrm{C}$ on a rotary evaporator under reduced pressure to obtain a white solid. Then the deuteration process was repeated using $10.0 \mathrm{~g}$ of $\mathrm{D}_{2} \mathrm{O}$ (100.0 at.\% D, Acros Organics) as the solvent for the once deuterated sample. The obtained solution was kept at room temperature for another week to guarantee further deuteration. The solution was again dried at $55{ }^{\circ} \mathrm{C}$ on a rotary evaporator under reduced pressure to obtain a white solid. The sample was further dried by evacuating on a Schlenk line at $200{ }^{\circ} \mathrm{C}$ for $12 \mathrm{~h}$ to eliminate remaining heavy water and then ground to fine powders in a glove box (water content and oxygen content both below $0.1 \mathrm{ppm}$ ).

\section{Water content determination}

The water content of purified [Gdm-H] $\mathrm{NfO}]$ was found to be less than 2000 ppm by volumetric Karl Fischer titration (870 KF Titrino plus, Metrohm).

\section{Fourier transform infrared (FTIR) analysis}

The FTIR spectra of the ([Gdm-H] $[\mathrm{NfO}]$ and $[\mathrm{Gdm}-\mathrm{D}][\mathrm{NfO}])$ powders at room temperature were recorded in the spectral range between 650 and $4000 \mathrm{~cm}^{-1}$ at a resolution of $4 \mathrm{~cm}^{-1}$ using an FTIR spectrometer (NEXUS, Thermo Nicolet) with a universal ATR accessory. 


\section{Thermogravimetric analysis (TGA)}

TGA measurements were performed on a STA 449 C Jupiter ${ }^{\circledR}$ simultaneous thermal analyzer (Netzsch). The sample was placed in an $\mathrm{Al}_{2} \mathrm{O}_{3}$ pan and heated from room temperature to $650{ }^{\circ} \mathrm{C}$ at a ramp of $5^{\circ} \mathrm{C} \mathrm{min}^{-1}$ in a nitrogen or air atmosphere $\left(50 \mathrm{~mL} \min ^{-1}\right)$. The onset temperature of mass loss was reported as the decomposition temperature $\left(T_{\mathrm{d}}\right)$.

Isothermogravimetric analysis (IGA) experiments were conducted on the same instrument under a nitrogen atmosphere $\left(50 \mathrm{~mL} \mathrm{~min}{ }^{-1}\right)$ at $150,225,250$ and $275{ }^{\circ} \mathrm{C}$, respectively. The initial mass of each sample was controlled to be around $11.1 \mathrm{mg}$. Prior to each IGA measurement, each sample was heated from room temperature to the target temperatures at a heating rate of $20{ }^{\circ} \mathrm{C} \mathrm{min}^{-1}$.

\section{Differential scanning calorimetry (DSC)}

DSC measurements were performed on a Pyris 1 Thermal Analysis System (PerkinElmer). Measurements were made between $-100{ }^{\circ} \mathrm{C}$ and $200{ }^{\circ} \mathrm{C}$ at heating/cooling rates of 10,15 and $20{ }^{\circ} \mathrm{C} \mathrm{min}^{-1}$. Three consecutive runs were conducted for each heating/cooling rate, wherein the first two heating/cooling scans were performed to eliminate the thermal history effects.

\section{X-ray diffraction (XRD)}

Temperature-dependent XRD measurements of fine powders of $[\mathrm{Gdm}-\mathrm{H}][\mathrm{NfO}]$ were performed from room temperature to $185{ }^{\circ} \mathrm{C}$ under vacuum on a powder X-ray diffractometer (X'Pert PRO DY2198, PANalytical) using $\mathrm{Cu} \mathrm{K} \alpha$ radiation $(\lambda=1.5406 \AA)$ to identify the solid-solid phase transitions. The sample was stabilized at each measurement temperature (accuracy: $\pm 1{ }^{\circ} \mathrm{C}$ ) for $2 \mathrm{~min}$ before each measurement. The measurement consisted of $\theta-2 \theta$ scan from $5^{\circ}$ to $50^{\circ}$ with a step size of $0.017^{\circ}$ and a scan speed of $0.4^{\circ} \mathrm{s}^{-1}$.

\section{Nuclear magnetic resonance (NMR) measurements}

NMR spectra were recorded on a Bruker Avance ${ }^{\mathrm{TM}}$ III $400 \mathrm{MHz}$ spectrometer at room temperature. $\delta_{\mathrm{H}}\left(400 \mathrm{MHz}, \mathrm{DMSO}-d_{6}, \delta /\right.$ ppm): $6.88\left(\mathrm{~s}, 6 \mathrm{H},\left[\mathrm{C}\left(\mathrm{NH}_{2}\right)_{3}\right]^{+}\right) ; \delta_{\mathrm{C}}\left(101 \mathrm{MHz}, \mathrm{DMSO}-d_{6}, \delta / \mathrm{ppm}\right)$ : 158.31. The concentration of the samples for ${ }^{1} \mathrm{H}$ NMR tests was controlled to be the same for all measurements.

\section{Morphological observations}

Polarized optical microscopy was used to confirm the solid-solid phase transitions or detect the possibility of partial melting via recording the morphological changes of fine powders of [Gdm-H] [NfO] during the heating scan $\left(5^{\circ} \mathrm{C} \mathrm{min}^{-1}\right)$ from $35^{\circ} \mathrm{C}$ to $190{ }^{\circ} \mathrm{C}$. The fine powders were placed between two thin glass plates and then heated on a Linkam TMS 93 heating/cooling microscope stage (accuracy: $\pm 0.1^{\circ} \mathrm{C}$ ) and focused on by an Olympus BX60 imaging microscope with a $10 \times / 0.30$ objective lens.

\section{Conductivity measurements}

The temperature and frequency dependence of the dielectric permittivity (dielectric constant) of $[\mathrm{Gdm}-\mathrm{H}][\mathrm{NfO}]$ was studied using an Alpha-Analyzer high resolution dielectric analyzer in the frequency range of $100 \mathrm{mHz}$ to $10 \mathrm{MHz}$ with an AC voltage of $100 \mathrm{mV}\left(V_{\mathrm{rms}}\right)$. The material was placed in a stainless steel conductivity cell (diameter: $20 \mathrm{~mm}$; thickness: $0.50 \mathrm{~mm}$ ) and then heated to $200{ }^{\circ} \mathrm{C}$ to ensure complete filling of the cell. The dielectric measurements were started at $200{ }^{\circ} \mathrm{C}$ followed by cooling to $-150{ }^{\circ} \mathrm{C}$ in steps of $2.5{ }^{\circ} \mathrm{C}$ at an initial rate of $10{ }^{\circ} \mathrm{C} \mathrm{min}^{-1}$, and then subjected to temperature stabilization for $10 \mathrm{~min}$. Afterwards, the sample was heated again from $-150{ }^{\circ} \mathrm{C}$ to $200{ }^{\circ} \mathrm{C}$ and finally cooled down again to room temperature. The temperature was controlled by liquid nitrogen gas flow via the Novocontrol Quatro Cryosystem. By correlating the amplitude and phase of the current passing through the dielectric sample capacitor with the applied AC voltage, the Alpha-Analyzer can calculate the complex impedance and capacity. From these data, the complex conductivity and permittivity can be calculated, respectively. The conductivity was determined by a plateau in the conductivity $v s$. frequency plot, which lies in between the subdiffusive conductivity region and the electrode polarization region as discussed below.

When measuring the ionic conductivity of ionic liquids as a function of AC-voltage frequency, there are three regions of the ionic conductivity, each of which reveals certain material and sample properties. ${ }^{13 a}$ At very high frequencies, the conductivity is dominated by the subdiffusive conductivity, as determined by the sample geometry, giving the appearance of very high conductivity. At the low frequency end, due to incomplete charge transfer between the electrode and the organic salt, the conductivity is hindered by the electric double layer $^{13 b}$ as a result of an effect known as electrode polarization, where the sample appears to have a very low conductivity. It is in the intermediate region that we can find the true sample conductivity, where the conductivity is high compared to the capacitive conductivity and low when compared to the electric double layer conductivity. For more information on how the ionic conductivity should be determined, we refer the readers to our previous work. ${ }^{13 a}$ The conductivity contribution from the empty cell is subtracted using a simple parallel impedance model, yielding the final conductivity. These steps are applied at every measurement temperature.

\section{Results and discussion}

\section{Infrared, thermal and structural analysis}

$\mathrm{NH}_{2} \mathrm{C}(=\mathrm{NH}) \mathrm{NH}_{2}$ is a very strong base with $\mathrm{p} K_{\mathrm{a}}=13.6 .{ }^{14}$ Its great basicity has been explained by Pauling ${ }^{15}$ in terms of extra resonance stabilization energy of the guanidinium ion of about 25-42 $\mathrm{kJ} \mathrm{mol}^{-1}$. The planarity of the $\mathrm{CN}_{3}$ skeleton corresponds to $\mathrm{sp}^{2}$ hybridization of the carbon atom. ${ }^{14}$ As shown in Fig. 1, the positive charge of guanidinium cation in the ground state is shared by the carbon atom and all three of the nitrogen atoms. ${ }^{16}$ Infrared analysis and NMR tests (Fig. 2 and $\mathrm{S} 1 \dagger$ ) confirm the completeness of the salt formation of $[\mathrm{Gdm}-\mathrm{H}][\mathrm{NfO}]$. Clearly, $[\mathrm{Gdm}-\mathrm{H}][\mathrm{NfO}]$ (i.e. $\quad\left[\mathrm{C}\left(\mathrm{NH}_{2}\right)_{3}\right]^{+}[n-$ $\left.\mathrm{C}_{4} \mathrm{~F}_{9} \mathrm{SO}_{3}\right]^{-}$) was formed at the equimolar composition according to the following equation: 


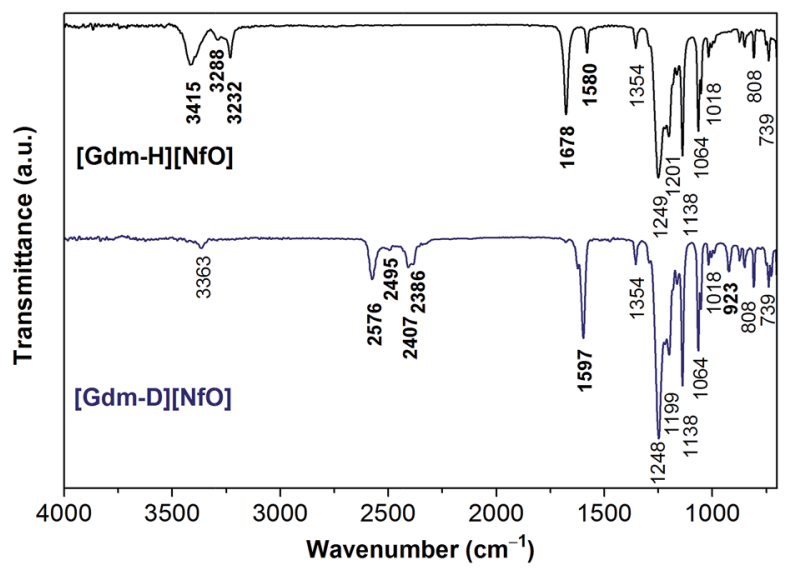

Fig. 2 FTIR spectra of [Gdm-H][NfO] and [Gdm-D][NfO].

$$
\begin{aligned}
& 2 \mathrm{NH}_{2} \mathrm{C}(=\mathrm{NH}) \mathrm{NH}_{2} \cdot \frac{1}{2} \mathrm{H}_{2} \mathrm{CO}_{3}+2 n-\mathrm{C}_{4} \mathrm{~F}_{9} \mathrm{SO}_{3} \mathrm{H} \rightarrow \\
& 2[\mathrm{Gdm}-\mathrm{H}][\mathrm{NfO}]+\mathrm{H}_{2} \mathrm{O}+\mathrm{CO}_{2} \uparrow
\end{aligned}
$$

By comparing the FTIR spectra of $[\mathrm{Gdm}-\mathrm{H}][\mathrm{NfO}]$ and $[\mathrm{Gdm}-$ D][NfO] (Fig. 2) as well as guanidine carbonate (Fig. S2 $\dagger$ ) and 1,2,4-triazolium nonaflate, ${ }^{5 a}$ the peaks at $3415,3288,3232,1678$ and $1580 \mathrm{~cm}^{-1}$ are attributed to the guanidinium cations $\left(\left[\mathrm{C}\left(\mathrm{NH}_{2}\right)_{3}\right]^{+}\right)^{16}$ while the absorption bands at $1354,1249,1201$, $1138,1064,1018,808$ and $739 \mathrm{~cm}^{-1}$ are associated with the nonaflate anions. In particular, for [Gdm- $\mathrm{H}][\mathrm{NfO}]$, the peaks at $3415 \mathrm{~cm}^{-1}$ and 3288 and $3232 \mathrm{~cm}^{-1}$ are due to asymmetric and symmetric $\mathrm{NH}_{2}$ stretching vibrations, respectively. ${ }^{16,17}$ The broadening of the bands in the region of $3200-3500 \mathrm{~cm}^{-1}$ indicates the formation of a hydrogen bonding network. ${ }^{18}$ Moreover, the sharp absorption bands at around 1249 and $1201 \mathrm{~cm}^{-1}$ may correspond to the $\mathrm{SO}_{3}$ asymmetric stretching vibration. ${ }^{19,20}$ This spectral feature is characteristic of a sulfonate anion strongly involved in a hydrogen bond..$^{20}$ The bands at $1678 \mathrm{~cm}^{-1}$ and $1580 \mathrm{~cm}^{-1}$ are assigned to the asymmetric $\mathrm{CN}_{3}$ degenerated stretching and the $\mathrm{NH}_{2}$ degenerated scissoring vibration, respectively. ${ }^{16}$ In addition, the complete removal of water and the absence of other-OH-containing species (e.g. sulfonic acid) were confirmed by the absence of the $\mathrm{H}-\mathrm{O}-\mathrm{H}$ bending band at around $1650 \mathrm{~cm}^{-1}$ and $\mathrm{O}-\mathrm{H}$ stretching bands in the region of $3500-3800 \mathrm{~cm}^{-1}$ in the infrared spectra (Fig. 2).

Upon deuteration of [Gdm- $\mathrm{H}][\mathrm{NfO}]$, considerably different spectra were obtained for deuterated guanidinium cations in [Gdm-D $][\mathrm{NfO}]$ while the frequencies of the bands assigned to nonaflate anions remained the same (Fig. 2). The bands associated with guanidinium cations are greatly red-shifted. For [Gdm-D][NfO], the peaks at $2576 \mathrm{~cm}^{-1}$ and 2407 and $2386 \mathrm{~cm}^{-1}$ correspond to the asymmetric and symmetric $\mathrm{ND}_{2}$ stretching vibrations, respectively. ${ }^{16}$ It is assumed that the stretching frequencies of the $\mathrm{N}-\mathrm{H}$ and $\mathrm{N}-\mathrm{D}$ bonds can be approximated by Hooke's law:21

$$
\bar{v}=\frac{1}{2 \pi c} \sqrt{\frac{m_{1}+m_{2}}{m_{1} m_{2}} f}
$$

where $\bar{v}$ is the wavenumber $\left(\mathrm{cm}^{-1}\right), c$ the velocity of light ( $\left.\mathrm{cm} \mathrm{s}^{-1}\right), m_{1}$ and $m_{2}$ the mass of atoms 1 and 2, respectively, in $g$, and $f$ the force constant of the bond (dyne $\mathrm{cm}^{-1}$ ). Using eqn (2) the ratio of the $\mathrm{N}-\mathrm{D}$ stretching frequency $v s$. the $\mathrm{N}-\mathrm{H}$ stretching frequency is calculated to be 0.730 . The experimental values of the ratio are $2576 \mathrm{~cm}^{-1} / 3415 \mathrm{~cm}^{-1}=0.754,2407 \mathrm{~cm}^{-1} /$ $3288 \mathrm{~cm}^{-1}=0.732$, and $2386 / 3232=0.738$, respectively, which agree well with the calculated value. In addition, the bands at $1597 \mathrm{~cm}^{-1}$ and $923 \mathrm{~cm}^{-1}$ are assigned to the asymmetric $\mathrm{CN}_{3}$ degenerated stretching and $\mathrm{ND}_{2}$ rocking, respectively. ${ }^{16}$ Interestingly, it seems that the $\mathrm{NH}_{2}$ degenerated scissoring vibration at $1580 \mathrm{~cm}^{-1}$ was red-shifted to a wavenumber of $1163 \mathrm{~cm}^{-1}$ (corresponding to $\mathrm{ND}_{2}$ degenerated scissors ${ }^{16}$ ) and meanwhile the $\mathrm{NH}_{2}$ rocking vibration in the vicinity of $1163 \mathrm{~cm}^{-1}$ is redshifted to $923 \mathrm{~cm}^{-1}$ after deuteration..$^{16}$ Particularly, the weak absorption bands at 3363 and $2495 \mathrm{~cm}^{-1}$ may represent the $\mathrm{N}-$ $\mathrm{H}$ and $\mathrm{N}-\mathrm{D}$ stretching vibrations of the residual NHD groups in the form of $\left[\mathrm{C}\left(\mathrm{ND}_{2}\right)_{2}(\mathrm{NHD})\right]^{+}$ions, respectively. ${ }^{14}$ Therefore, the deuterated product [Gdm-D][NfO] obtained in this work is actually a mixture of $\left[\mathrm{C}\left(\mathrm{ND}_{2}\right)_{3}\right]^{+}\left[n-\mathrm{C}_{4} \mathrm{~F}_{9} \mathrm{SO}_{3}\right]^{-}$and $\left[\mathrm{C}\left(\mathrm{ND}_{2}\right)_{2}\right.$ (NHD) $]^{+}\left[n-\mathrm{C}_{4} \mathrm{~F}_{9} \mathrm{SO}_{3}\right]^{-}$.

Furthermore, based on the FTIR data, the deuteration percentage (percentage of deuterium substitution) of [Gdm-D] [NfO] was calculated to be $92.0 \%$. This value was calculated as follows: (i) firstly, the area of the absorption peak at $1354 \mathrm{~cm}^{-1}$ attributed purely to nonaflate anions and the area of absorption peak attributed to $\mathrm{NH}$ stretching vibrations in the region of $3175-3500 \mathrm{~cm}^{-1}$ before and after deuteration were integrated respectively; (ii) secondly, the area of the absorption peak attributed to the NH stretching vibrations was divided by the corresponding area of the absorption peak at $1354 \mathrm{~cm}^{-1}$ before and after deuteration; (iii) thirdly, the "normalized" area of the absorption peak attributed to the NH stretching vibration after deuteration was divided by the corresponding "normalized" area before deuteration, resulting in a ratio; (iv) finally, deuteration percentage is equal to $(1-$ ratio $) \times 100 \%$.

Meanwhile, as shown in the ${ }^{1} \mathrm{H}-\mathrm{NMR}$ spectra of [Gdm-H] [NfO] and [Gdm-D][NfO] (Fig. S1 $\dagger$ ), the signals of the acidic hydrogens arise at $6.88 \mathrm{ppm}\left(\mathrm{C}-\mathrm{NH}_{2}\right)$ in $[\mathrm{Gdm}-\mathrm{H}][\mathrm{NfO}]$ and $6.89 \mathrm{ppm}(\mathrm{C}-\mathrm{NHD})$ in [Gdm-D][NfO]. From the relative integrated areas of the peaks for acidic hydrogens $v s$. the corresponding peak area at $\sim 2.50 \mathrm{ppm}$ (solvent DMSO- $d_{6}$ ), the deuteration percentage of the acidic hydrogens in [Gdm-D] [NfO] was estimated to be about (14.46-1.02)/14.46 $\times 100 \%=$ 92.9\%. Clearly, the FTIR spectra and ${ }^{1} \mathrm{H}$ NMR spectra are in good agreement for the determination of deuteration percentage. As $1-92 \%=0.08 \approx 1 / 2 \times 1 / 6$, it was further

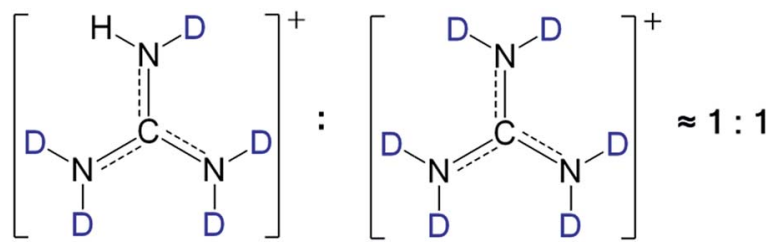

Fig. 3 The speculated molar ratio of $\left[C\left(\mathrm{ND}_{2}\right)_{2}(\mathrm{NHD})\right]^{+}$vs. $\left[\mathrm{C}\left(\mathrm{ND}_{2}\right)_{3}\right]^{+}$in deuterated guanidinium cations of [Gdm-D][NfO] is around $1: 1$. 


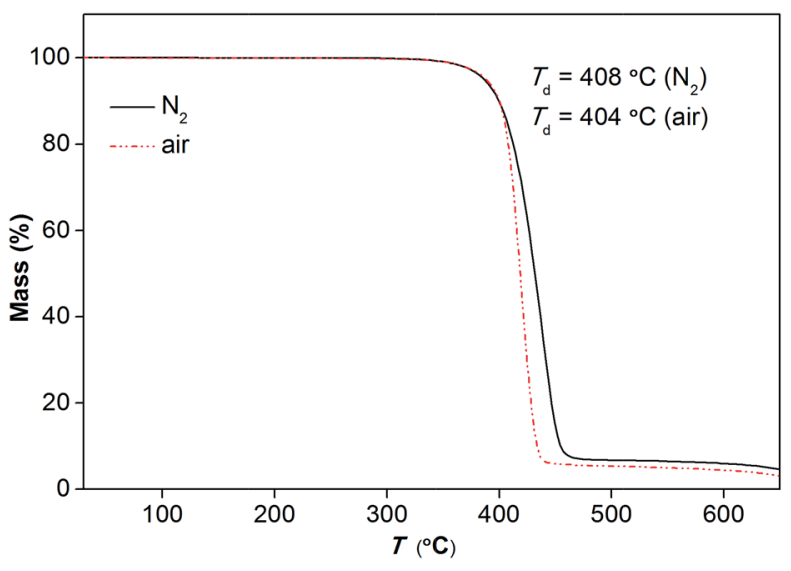

Fig. 4 TGA traces of [Gdm-H][NfO] in nitrogen gas and air, respectively. Heating rate: $5^{\circ} \mathrm{C} \mathrm{min}^{-1}$; gas flow rate: $50 \mathrm{~mL} \mathrm{~min}{ }^{-1}$; mass of sample: $16.850 \mathrm{mg}$ (nitrogen gas) and $16.630 \mathrm{mg}$ (air).

concluded that the molar ratio of $\left[\mathrm{C}\left(\mathrm{ND}_{2}\right)_{2}(\mathrm{NHD})\right]^{+}\left[n-\mathrm{C}_{4} \mathrm{~F}_{9} \mathrm{SO}_{3}\right]^{-}$

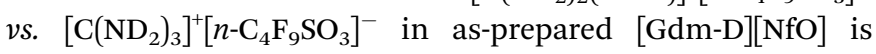
around $1: 1$ (Fig. 3).

Fig. 4 represents the TGA traces of $[\mathrm{Gdm}-\mathrm{H}][\mathrm{NfO}]$ in nitrogen and air atmospheres at a heating rate of $5 \mathrm{~K} \mathrm{~min}^{-1}$, respectively. It shows that $[\mathrm{Gdm}-\mathrm{H}][\mathrm{NfO}]$ has a high thermal stability with a one-step weight loss event and a $T_{\mathrm{d}}$ as high as $408{ }^{\circ} \mathrm{C}$ in a nitrogen atmosphere. The TGA trace in air atmosphere confirms the thermooxidative stability of $[\mathrm{Gdm}-\mathrm{H}][\mathrm{NfO}]\left(T_{\mathrm{d}}=\right.$ $\left.404{ }^{\circ} \mathrm{C}\right)$. The gas atmosphere seems to have little influence on the thermal stability of the protic salt.

Furthermore, isothermogravimetric analysis (IGA) performed at $150{ }^{\circ} \mathrm{C}$ (Fig. 5) indicates that [Gdm-H][NfO] shows superior thermal stability and negligible vapor pressure compared with model organic molecular proton conductors like imidazole $\left(T_{\mathrm{mp}}=89^{\circ} \mathrm{C}, T_{\mathrm{bp}}=256^{\circ} \mathrm{C}\right)$ and $1 H-1,2,4$-triazole $\left(T_{\mathrm{mp}}\right.$

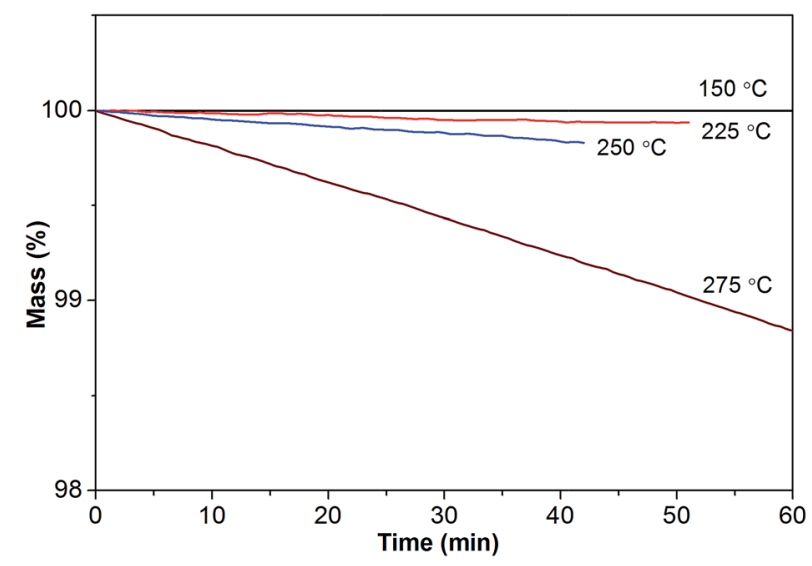

Fig. 5 Isothermogravimetric analysis of [Gdm-H][NfO] at four discrete temperatures under nitrogen purge $\left(50 \mathrm{~mL} \mathrm{~min}^{-1}\right)$. Mass loss rate (expressed as the change in mass percent with time, $\mathrm{d} \alpha / \mathrm{d} t=(\mathrm{d} m / \mathrm{d} t) /$ $m_{0}$, where $m_{0}$ is the initial mass): $\mathrm{d} \alpha / \mathrm{d} t=0.00138 \% \mathrm{~min}^{-1}$ at $T=$ $225^{\circ} \mathrm{C}\left(R^{2}=0.96694\right) ; \mathrm{d} \alpha / \mathrm{d} t=0.00383 \% \mathrm{~min}^{-1}$ at $T=250{ }^{\circ} \mathrm{C}\left(R^{2}=\right.$ $0.99623) ; \mathrm{d} \alpha / \mathrm{d} t=0.01932 \% \mathrm{~min}^{-1}$ at $T=275^{\circ} \mathrm{C}\left(R^{2}=0.99976\right)$. Note that $\mathrm{d} m / \mathrm{d} t=m_{0}(\mathrm{~d} \alpha / \mathrm{d} t)$. The initial mass of each sample was controlled to be about $11.1 \mathrm{mg}$. $\left.=120^{\circ} \mathrm{C}, T_{\mathrm{bp}}=260^{\circ} \mathrm{C}\right),{ }^{5 a, 22}$ as well as conventional electrolytes like Nafion ${ }^{\circledR}$ membranes ${ }^{11 a}$ and $85 \% \mathrm{H}_{3} \mathrm{PO}_{4} \cdot{ }^{23}$ The negligible volatility of $[\mathrm{Gdm}-\mathrm{H}][\mathrm{NfO}]$ as a solid-state proton conductor makes it a better candidate than molecular species for longterm device use. To quantify the volatility of [Gdm-H][NfO], IGA tests were also carried out at three other discrete temperatures well below $T_{\mathrm{d}}: 225,250$ and $275{ }^{\circ} \mathrm{C}$. These temperatures were chosen because $[\mathrm{Gdm}-\mathrm{H}][\mathrm{NfO}]$ is chemically stable and exhibits measurable weight losses in this regime. As can be seen in Fig. 5, the IGA mass loss curves are all linear. Clearly, the higher the temperature, the faster the mass loss. The high linearity associated with the IGA curves reveals pseudo-zero-order mass loss kinetics, providing strong evidence that the observed decrease in mass over time at constant temperature results from vaporization of the protic salt itself rather than evolution of thermal degradation products or impurities. ${ }^{24,25}$

Based on the linear (zero-order) evaporative mass losses for [Gdm-H][NfO], an enthalpy of vaporization, $\Delta_{\mathrm{vap}} H$, of $120.9 \mathrm{~kJ}$ $\mathrm{mol}^{-1}$ was estimated (Fig. 6), using the following regression equation derived from the Clausius-Clapeyron relationship: ${ }^{24}$

$$
\ln \left[T^{1 / 2}\left(\frac{\mathrm{d} m}{\mathrm{~d} t}\right)\right]=c^{\prime}-\frac{\Delta_{\mathrm{vap}} H}{R T}
$$

where $T$ is the absolute temperature in Kelvin, $\mathrm{d} m / \mathrm{d} t$ the rate of mass loss per unit area, $c^{\prime}$ a constant, and $R$ the universal gas constant $\left(8.314 \mathrm{~J} \mathrm{~mol}^{-1} \mathrm{~K}^{-1}\right)$. In addition, a very similar value of $\Delta_{\text {vap }} H=121.3 \mathrm{~kJ} \mathrm{~mol}^{-1}$ (Fig. S3 and S4 $\dagger$ ) was obtained for [Gdm$\mathrm{H}][\mathrm{NfO}]$ even though IGA tests were conducted with different initial masses of the sample (between $6 \mathrm{mg}$ and $15 \mathrm{mg}$ ) as well as a different nitrogen flow rate $\left(60 \mathrm{~mL} \mathrm{~min}{ }^{-1}\right)$, indicating a good reproducibility of the estimated result. Remarkably, the estimated value of $\Delta_{\mathrm{vap}} H$ is comparable to that of 1-butyl-3methylimidazolium bis(trifluoromethylsulfonyl)imide ([bmim] $\left[\mathrm{Tf}_{2} \mathrm{~N}\right], \Delta_{\mathrm{vap}} H=118.5 \mathrm{~kJ} \mathrm{~mol}^{-1}$ ), which is an aprotic ionic liquid. ${ }^{24}$

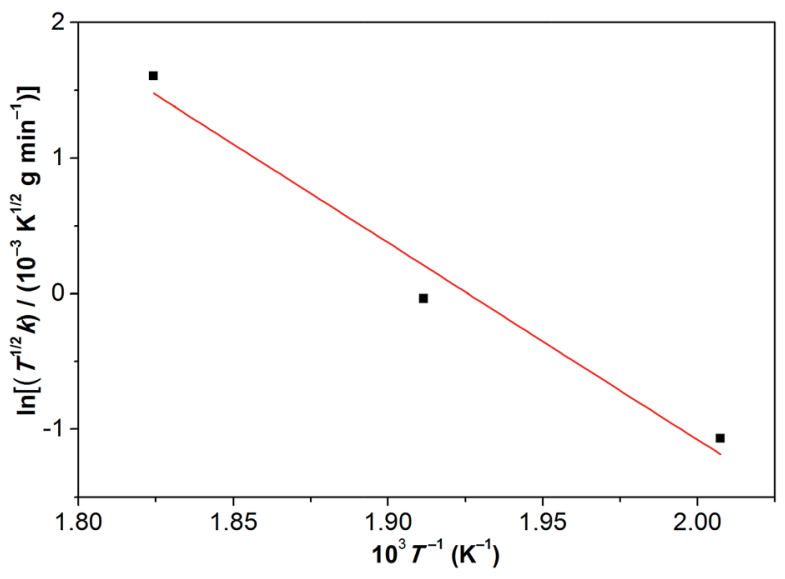

Fig. 6 Temperature dependence of the mass loss for [Gdm-H][NfO] based on the IGA results shown in Fig. 5. Such a plot yields a slope of $-\Delta_{\text {vap }} H /(1000 R)$, where $\Delta_{\text {vap }} H$ is the enthalpy of vaporization, $R$ is the universal gas constant, and $k$ equals to $\mathrm{d} m / \mathrm{d} t=m_{0}(\mathrm{~d} \alpha / \mathrm{d} t)$, which is the rate of mass loss per unit area shown in eqn (3). Correlation coefficient $\left(R^{2}\right): 0.95053$ 
Furthermore, the high thermal stability can be correlated with $\Delta \mathrm{p} K_{\mathrm{a}}$, which denotes the difference in aqueous solution $\mathrm{p} K_{\mathrm{a}}$ values for the constituent base and acid of the protic salt. The $\mathrm{p} K_{\mathrm{a}}$ value of $n-\mathrm{C}_{4} \mathrm{~F}_{9} \mathrm{SO}_{3} \mathrm{H}$ can be estimated to be the same as that of $\mathrm{CF}_{3} \mathrm{SO}_{3} \mathrm{H}\left(\mathrm{p} K_{\mathrm{a}}=-13\right) .{ }^{5 a, 26}$ Since the reported $\mathrm{p} K_{\mathrm{a}}$ value of guanidine is $13.6,{ }^{\mathbf{1 4 2} 27} \Delta \mathrm{p} K_{\mathrm{a}}$ of the protic salt $[\mathrm{Gdm}-\mathrm{H}][\mathrm{NfO}]$ is estimated to be 26.6, suggesting the complete proton transfer from $n-\mathrm{C}_{4} \mathrm{~F}_{9} \mathrm{SO}_{3} \mathrm{H}$ to guanidine $\left(\Delta \mathrm{p} K_{\mathrm{a}}>10\right),{ }^{28}$ leading to the superior thermal stability, low volatility and high $\Delta_{\mathrm{vap}} H$ of $[\mathrm{Gdm}-\mathrm{H}][\mathrm{NfO}]$. In addition to the superior thermal stability of [Gdm-H][NfO], guanidinium cations and perfluorobutanesulfonate anions have been reported to exhibit adequate electrochemical stability on platinum working electrodes for fuel cells. ${ }^{12 a, 29}$

The structural phase transitions of $[\mathrm{Gdm}-\mathrm{H}][\mathrm{NfO}]$ accompanied by thermodynamic anomalies were revealed by DSC measurements (Fig. 7, S5 and S6 ${ }^{\dagger}$ ). During the heating scan in the DSC measurements recorded at $15{ }^{\circ} \mathrm{C} \min ^{-1}$ (Fig. 7), five distinct endothermic transitions were observed at $71.8{ }^{\circ} \mathrm{C}$, $87.8{ }^{\circ} \mathrm{C}, 117.6{ }^{\circ} \mathrm{C}, 141.9{ }^{\circ} \mathrm{C}$ and $186.2{ }^{\circ} \mathrm{C}$, respectively, with the last temperature corresponding to the melting point of [Gdm-H] [NfO]. Onset temperatures $(T)$, enthalpy changes $(\Delta H)$ and entropy changes $(\Delta S)$ of the main phase transitions of [Gdm-H] [NfO] are summarized in Table 1 . The entropy of fusion, $\Delta S_{\mathrm{f}}$, at the melting point of $186.2{ }^{\circ} \mathrm{C}$ was calculated to be as low as $17.70 \mathrm{~J} \mathrm{~K}^{-1} \mathrm{~mol}^{-1}\left(\Delta S_{\mathrm{f}}=\Delta H_{\mathrm{f}} / T_{\mathrm{m}}\right)$, which is much smaller than $\Delta S_{\mathrm{f}}$ of many reported OIPCs ${ }^{5 a, 11 a, 12,30}$ (e.g. $46.0 \mathrm{~J} \mathrm{~K}^{-1} \mathrm{~mol}^{-1}$ for 1,2,4-triazolium nonaflate ${ }^{5 a}$ and $62.8 \mathrm{~J} \mathrm{~K}^{-1} \mathrm{~mol}^{-1}$ for guanidinium triflate ${ }^{\mathbf{1 2}}$ ) and is even in line with Timmerman's criterion for molecular plastic crystals $\left(\Delta S_{\mathrm{f}}<20 \mathrm{~J} \mathrm{~K}^{-1} \mathrm{~mol}^{-1}\right){ }^{31}$ The low entropy of fusion is attributed to the multiple endothermic transitions prior to melting, which are associated with solidsolid phase transitions and onset of ion rotations or reorientations, ${ }^{5 \boldsymbol{a , 8 , 9}}$ resulting in a large extent of orientational freedom and hence greatly increased disorder in the high

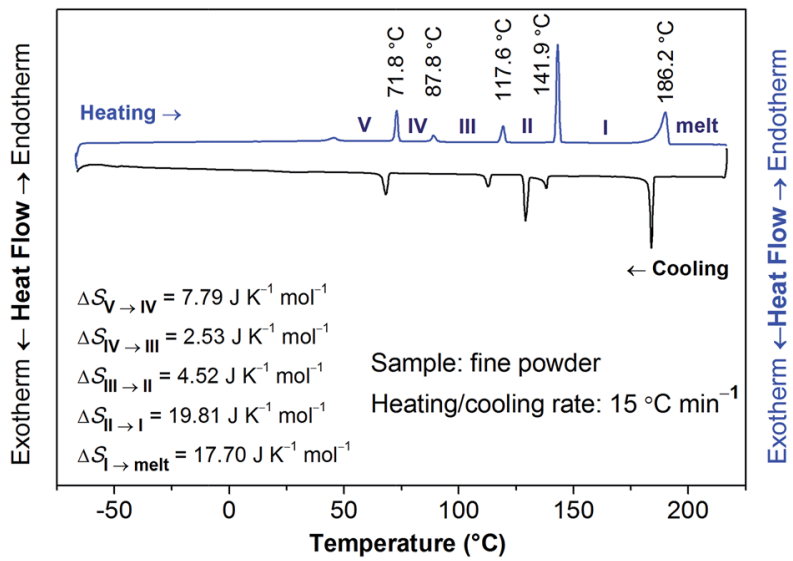

Fig. 7 DSC thermograms of $[\mathrm{Gdm}-\mathrm{H}][\mathrm{NfO}]$ in the form of fine powders measured at $15^{\circ} \mathrm{C}$ min $^{-1}$ for both the heating and cooling scans. The onset temperatures and entropy changes for each phase transition during the heating scan are given. Each solid phase is labeled by Roman numerals with the highest temperature solid phase denoted by phase I. The melt phase is also indicated. The peak temperature of melting is $190^{\circ} \mathrm{C}$.
Table 1 Onset temperatures $(T)$, enthalpy changes $(\Delta H)$ and entropy changes $(\Delta S)$ of phase transitions of [Gdm-H][NfO]

\begin{tabular}{lrll}
\hline Phase transition & $T /{ }^{\circ} \mathrm{C}$ & $\Delta H / \mathrm{kJ} \mathrm{mol}^{-1}$ & $\Delta S / \mathrm{J} \mathrm{K}^{-1} \mathrm{~mol}^{-1}$ \\
\hline $\mathrm{V} \rightarrow$ IV & 71.8 & 2.69 & 7.79 \\
IV $\rightarrow$ III & 87.8 & 0.91 & 2.53 \\
III $\rightarrow$ II & 117.6 & 1.77 & 4.52 \\
II $\rightarrow$ I & 141.9 & 8.22 & 19.81 \\
I $\rightarrow$ melt & 186.2 & 8.13 & 17.70 \\
\hline
\end{tabular}

temperature plastic crystalline phase. Consequently, the majority of the entropy changes are released prior to the melting transition, leading to a low entropy of fusion. Likely, both the cations and anions are highly disordered in phase I, indicating high ionic conductivity in phase I.

The entropy changes $(\Delta S)$ of phase transitions of $\mathrm{V} \rightarrow \mathrm{IV}$, IV $\rightarrow$ III, III $\rightarrow$ II, and II $\rightarrow$ I are 7.79, 2.53, 4.52, and $19.81 \mathrm{~J} \mathrm{~K}^{-1} \mathrm{~mol}^{-1}$, respectively. Assuming that the configurational entropy is the most dominant contribution for solid-solid phase transitions, the entropy change can be approximated according to Boltzmann's equation:

$$
\Delta S=R \times \ln \left(n_{1} / n_{2}\right)
$$

where $n_{1} / n_{2}$ is the ratio of the numbers of respective orientational freedoms (geometrically distinguishable orientations) of constituent molecules in the high and low temperature phases. ${ }^{32}$ In particular, a ratio of 10.8 is obtained for $\Delta S_{\mathrm{II} \rightarrow \mathrm{I}}$ and this value is considered to account for the change in the number of orientations of all ions at $T_{\mathrm{II} \rightarrow \mathrm{I}}$, suggesting clearly an orderdisorder feature. ${ }^{33}$ Meanwhile, the ratio for the phase transition of IV $\rightarrow$ III is as small as 1.36 and close to 1 , which may suggest a displacive phase transition. ${ }^{34}$

To clarify whether these phase transitions are first-order, DSC measurements at three different heating/cooling rates were performed (Fig. 7, S5 and S6 ${ }^{\dagger}$ ). The reversible heat anomalies at $71.8{ }^{\circ} \mathrm{C} / 69.6{ }^{\circ} \mathrm{C}, 117.6{ }^{\circ} \mathrm{C} / 114.1{ }^{\circ} \mathrm{C}$, and $141.9{ }^{\circ} \mathrm{C} / 139.0{ }^{\circ} \mathrm{C}$ (on heating/cooling shown in Fig. 7) display well-shaped peaks and temperature hysteresis. For the phase transition of III $\rightarrow$ II, the limiting temperature hysteresis estimated from the scans extrapolated to a scanning rate of $0{ }^{\circ} \mathrm{C} \mathrm{min}^{-1}$ is $3.13^{\circ} \mathrm{C}$ (Fig. $\mathrm{S} 7 \dagger$ ) and far greater than $0{ }^{\circ} \mathrm{C}$, indicating a first-order solid-solid phase transition. Similarly, the limiting temperature hysteresis for the phase transition of II $\rightarrow$ I at a scanning rate of $0{ }^{\circ} \mathrm{C} \min ^{-1}$ is $2.30{ }^{\circ} \mathrm{C}$ (Fig. 8), demonstrating again a first-order phase transition. The phase transition of $\mathrm{V} \rightarrow$ IV also seems to be a first-order phase transition. In addition, it is worth mentioning that the " $\lambda$ " shape of the weak anomaly peak happening well ahead of the phase transition of V $\rightarrow$ IV (Fig. 7, S5 and S6 $\dagger^{\dagger}$ ) resembles the features of a second-order phase transition, like that of triglycine sulfate. ${ }^{35}$ Furthermore, polarized optical microscopic observations exclude the possibility of partial melting of $[\mathrm{Gdm}-\mathrm{H}][\mathrm{NfO}]$ during the solid-solid phase transitions of $\mathrm{V} \rightarrow$ IV, IV $\rightarrow$ III, III $\rightarrow$ II and II $\rightarrow$ I (Fig. S8S10†) while it detects partial melting shortly before the phase 

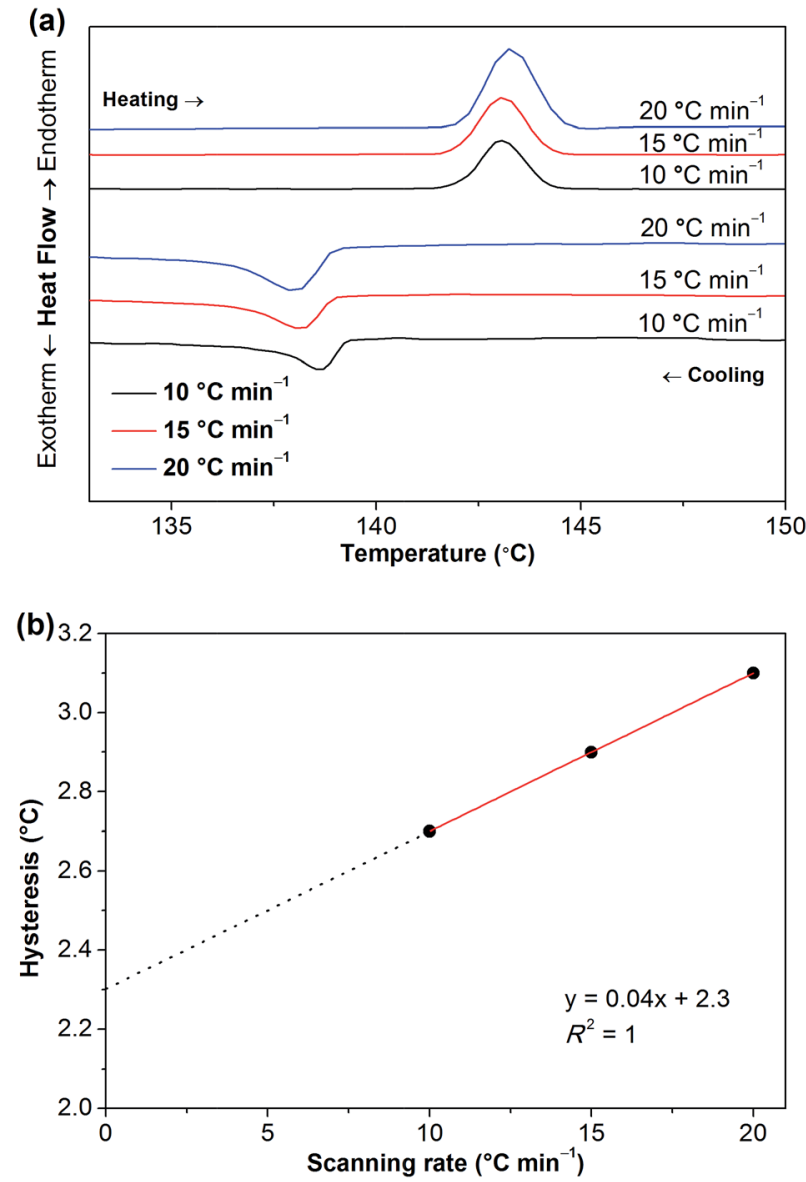

Fig. 8 (a) DSC curves of [Gdm-H][NfO] at different heating/cooling rates showing in particular the phase transition of $\mathrm{II} \rightarrow$ I during the heating scan and the reverse phase transition during the cooling scan; (b) the corresponding limiting temperature hysteresis $\left(2.30^{\circ} \mathrm{C}\right)$ estimated from the scans extrapolated to a scanning rate of $0^{\circ} \mathrm{C} \mathrm{min}^{-1}$, demonstrating a first-order solid-solid phase transition. Correlation coefficient $\left(R^{2}\right): 1$.

transition of phase I $\rightarrow$ melt (Fig. 7, S11-S13†), which will be discussed later on.

During the cooling scan, $[\mathrm{Gdm}-\mathrm{H}][\mathrm{NfO}]$ crystallizes at around $185.1^{\circ} \mathrm{C}$ with a sudden release of latent heat, which is similar to the behavior of some reported plastic crystals. ${ }^{5 a, 36}$

To further investigate the phase transitions as shown in the DSC trace (Fig. 7), fine powders of [Gdm-H][NfO] were heated under vacuum from $25{ }^{\circ} \mathrm{C}$ to $185^{\circ} \mathrm{C}$ and the structural features were monitored by temperature-dependent powder XRD. As shown in Fig. 9, several diffraction peaks disappear or appear during these endothermic transitions. When the sample was heated from $25{ }^{\circ} \mathrm{C}$ to $86{ }^{\circ} \mathrm{C}$, the powder XRD patterns were basically the same. From $86^{\circ} \mathrm{C}$ to $89^{\circ} \mathrm{C}$, a new diffraction peak appears at $2 \theta=10.5^{\circ}$, which becomes more and more evident as the temperature increases to $185^{\circ} \mathrm{C}$, confirming the solid-solid phase transition of IV $\rightarrow$ III at $87.8{ }^{\circ} \mathrm{C}$. From $113{ }^{\circ} \mathrm{C}$ onwards, a new reflection appears at $2 \theta=5.2^{\circ}$, which also becomes a major reflection at $185{ }^{\circ} \mathrm{C}$ in the high temperature plastic crystalline phase (phase I) and is in accordance with the solidsolid phase transition of III $\rightarrow$ II at $117.6{ }^{\circ} \mathrm{C}$. From $119{ }^{\circ} \mathrm{C}$ to $143^{\circ} \mathrm{C}$, a number of minor diffraction peaks $\left(\right.$ e.g. $2 \theta=5.7^{\circ}, 8.6^{\circ}$, $9.9^{\circ}, 11.5^{\circ}, 14.9^{\circ}$ and $19.9^{\circ}$ ) vanish gradually and meanwhile a new diffraction peak appears at $2 \theta=21.4^{\circ}$, agreeing well with the phase transition of II $\rightarrow$ I at $141.9^{\circ} \mathrm{C}$ and the relatively large entropy change of $19.81 \mathrm{~J} \mathrm{~K}^{-1} \mathrm{~mol}^{-1}$. This indicates a transformation between two different crystalline structures and likely an increase in symmetry. The slight difference in onset temperatures of lattice transformation and thermal transition should be related to the different heating methods for powder XRD and DSC measurements..$^{5 a, 11 a}$

From $143^{\circ} \mathrm{C}$ to $180^{\circ} \mathrm{C}$, the powder XRD patterns were similar except that some weak reflections appear or disappear during this process. Furthermore, the baselines for the powder XRD patterns are relatively flat in the higher angle diffraction region at all temperatures, indicating a high level of crystallinity in $[\mathrm{Gdm}-\mathrm{H}][\mathrm{NfO}] .^{37}$ Compared with the powder XRD patterns of the lower temperature phases, the powder XRD patterns of phase I are simpler, implying a crystal lattice of higher symmetry. ${ }^{5 a, 11 a, 32 a, 36 a}$ In fact, the reduction of the number of diffraction peaks in phase I indicates the presence of stronger dynamic rotational disorder which leads to the plastic properties, low entropy of fusion (Fig. 7), and significant ionic conductivity (Fig. 10). Therefore, powder XRD measurements reveal that $[\mathrm{Gdm}-\mathrm{H}][\mathrm{NfO}]$ exhibits short-range disorder and long-range positional order in the high-temperature plastic crystalline phase.

From $180^{\circ} \mathrm{C}$ to $185^{\circ} \mathrm{C}$, some diffraction peaks $\left(\right.$ e.g. $2 \theta=5.2^{\circ}$, $10.5^{\circ}, 15.8^{\circ}, 21.1^{\circ}$ and $26.5^{\circ}$ ) become sharper and more intense while some diffraction peaks disappear (e.g. $2 \theta=13.7^{\circ}, 18.7^{\circ}$ and $20.2^{\circ}$ ). However, based on polarized optical microscopic observations, during the heating scan from $173{ }^{\circ} \mathrm{C}$ to $185{ }^{\circ} \mathrm{C}$ (Fig. S11-S13†), some crystals begin to melt, corresponding well to the relatively broad and less symmetrical melting peak rather than a sharp transition observed in DSC thermograms (Fig. 7), although the oneset temperature and peak temperature of melting are $186.2^{\circ} \mathrm{C}$ and $190{ }^{\circ} \mathrm{C}$, respectively. In particular, some single crystals are observed to swim in a melt (Fig. S12 and S13†), indicating clearly partial melting. Currently, we are not clear about the mechanism of partial melting. It is speculated that a tiny trace of impurities (e.g. $\mathrm{CO}_{3}{ }^{2-}, \mathrm{Cl}^{-}, \mathrm{SO}_{4}{ }^{2-}$ and $\mathrm{Na}^{+}$ from the starting materials) may lead to partial melting of $[\mathrm{Gdm}-\mathrm{H}][\mathrm{NfO}]$. Further work on the mechanism will be explored in our labs.

\section{Ionic conductivity}

The temperature dependence of the anhydrous ionic conductivity of $[\mathrm{Gdm}-\mathrm{H}][\mathrm{NfO}]$ was derived via dielectric measurements (Fig. 10). Both temperature-dependent ionic conductivity (Fig. 10 and 11) and powder XRD measurements (Fig. 9) show no evident change for the phase transformation of $\mathrm{V} \rightarrow$ IV at $71.8{ }^{\circ} \mathrm{C}$ (Fig. 7). As the temperature increases, obvious jumps in the ionic conductivity are observed at $88^{\circ} \mathrm{C}$, $114{ }^{\circ} \mathrm{C}$ and $136^{\circ} \mathrm{C}$, agreeing well with the phase transitions of IV $\rightarrow$ III, III $\rightarrow$ II and II $\rightarrow$ I as shown in the DSC trace (Fig. 7) and variable temperature powder XRD measurement results (Fig. 9). 


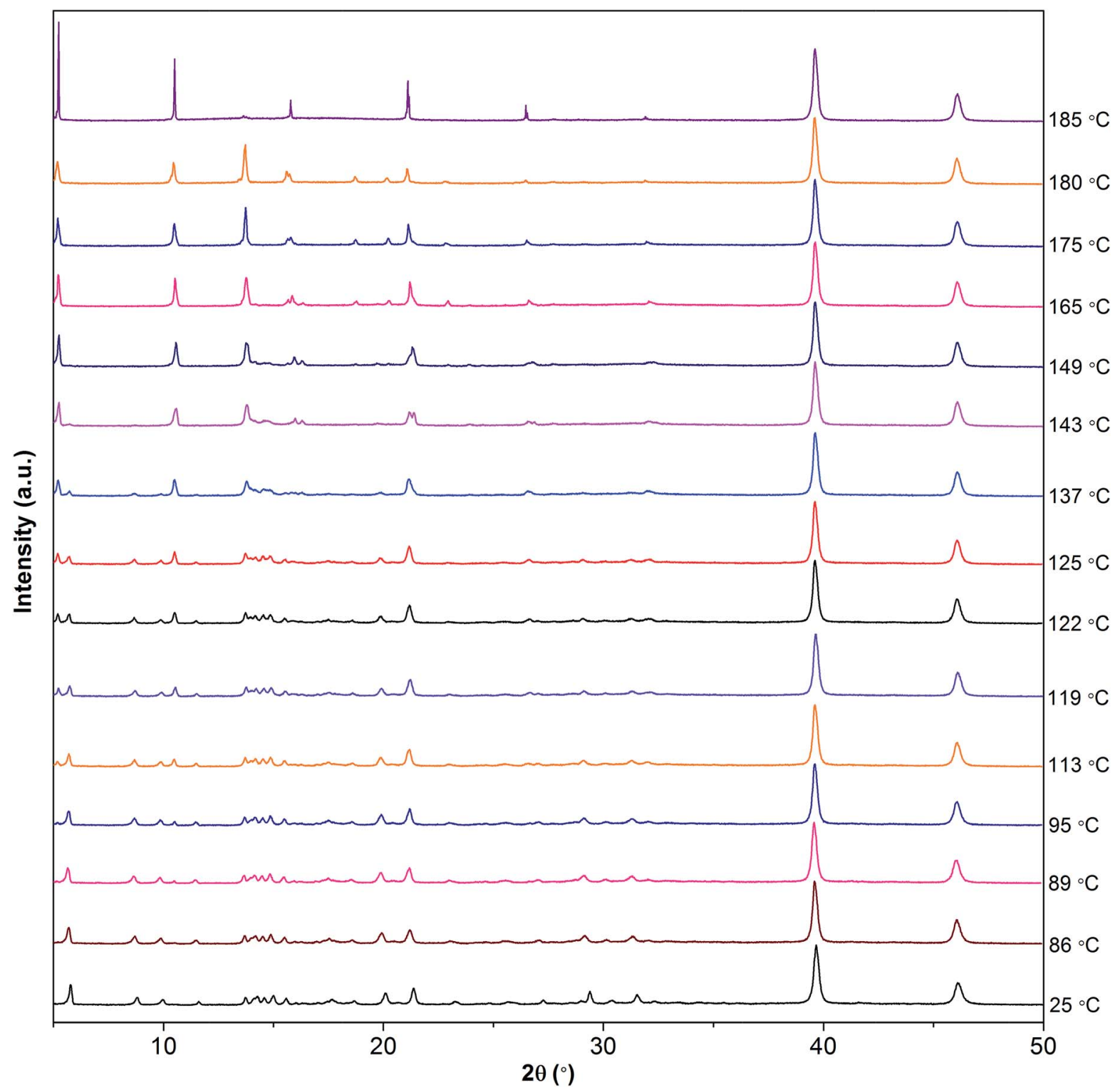

Fig. 9 Powder XRD patterns of [Gdm]][NfO] as a function of temperature, demonstrating structural changes with increasing temperature.

Above $176{ }^{\circ} \mathrm{C}$, the solid-state ionic conductivity exceeds $1 \times$ $10^{-4} \mathrm{~S} \mathrm{~cm}^{-1}$ prior to its melting transition at around $186.2^{\circ} \mathrm{C}$, which is correlated with the accompanied partial melting in this temperature region (Fig. S12 and S13†). The anhydrous ionic conductivity even reaches $2.1 \times 10^{-3} \mathrm{~S} \mathrm{~cm}^{-1}$ at $185^{\circ} \mathrm{C}$, which is comparable to the ionic conductivity of one of the state-of-theart hydrated metal-organic framework (MOF) based proton conductors $\left(3.9 \times 10^{-3} \mathrm{~S} \mathrm{~cm}^{-1}\right.$ at $98 \%$ relative humidity at $\left.25{ }^{\circ} \mathrm{C}\right) .^{38}$ However, this region is actually a non-equilibrium process with the sample melting continuously in the temperature range of $176-186{ }^{\circ} \mathrm{C}$. Consequently, more cations and anions become 'free' and contribute to the ionic conductivity, and thereby the ionic conductivity shows a drastic increase.

Remarkably, in the temperature window between $75{ }^{\circ} \mathrm{C}$ and $172.5^{\circ} \mathrm{C}$, the measured ionic conductivity of $[\mathrm{Gdm}-\mathrm{H}][\mathrm{NfO}]$ is about one order of magnitude higher than that of pure guanidinium triflate $([\mathrm{Gdm}-\mathrm{H}][\mathrm{TfO}])^{12 b}$ in the solid state. In addition, in the high-temperature plastic crystalline phase, [Gdm-H][NfO] also shows superior ionic conductivity compared with 1,2,4triazolium nonaflate. ${ }^{5 a}$ This is correlated with the significantly lower $\Delta S_{\mathrm{f}}$ of $[\mathrm{Gdm}-\mathrm{H}][\mathrm{NfO}]$ compared with the two structurally similar analogues, which are also POIPCs, indicating the significance of both cation and anion in the ion-conducting behavior of POIPCs. Noticeably, pure, highly ion-conductive POIPCs like [Gdm-H][NfO] obviate the shortcomings of doped plastic crystals (including POIPCs), ${ }^{5 a, 12,39,40}$ such as the need for dopants, the risk of acid leaching and corrosion, insufficient thermal stability, and the possible incompatability of dopants with plastic crystal matrices. In addition, $[\mathrm{Gdm}-\mathrm{H}][\mathrm{NfO}]$ exhibits superior ionic conductivity compared with the inorganic proton conductor $\mathrm{CsH}_{2} \mathrm{PO}_{4}$ measured under humidified air with a constant water content of $12 \mathrm{~mol} \% .^{41}$

To further analyze the ion-conducting behavior of [Gdm- $\mathrm{H}]$ [NfO], the Arrhenius plot of the ionic conductivity of [Gdm-H] 


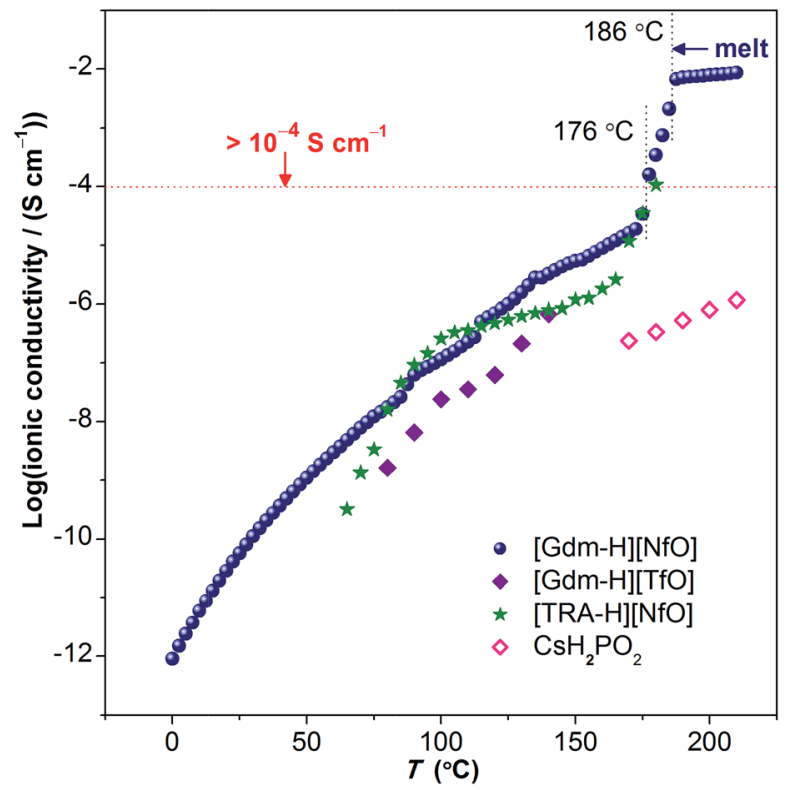

Fig. 10 lonic conductivity of [Gdm-H][NfO] as a function of temperature. Above $176{ }^{\circ} \mathrm{C}$ where partial melting happens, the ionic conductivity exceeds $1 \times 10^{-4} \mathrm{~S} \mathrm{~cm}^{-1}\left(0.1 \mathrm{mS} \mathrm{cm}^{-1}\right)$ prior to the melting transition at $186.2{ }^{\circ} \mathrm{C}$ and is marked by dotted vertical lines. The solid navy balls represent the ionic conductivity of [Gdm-H][NfO] derived via dielectric measurements. For comparison, the ionic conductivities of other solid-state proton conductors (in the form of pressed pellets), such as guanidinium triflate ([Gdm-H][TfO]), ${ }^{12 b} 1,2,4-$ triazolium nonaflate ([TRA-H][NfO]), ${ }^{5 a}$ and $\mathrm{CsH}_{2} \mathrm{PO}_{4}$ (measured under humidified air with a constant water content of $12 \mathrm{~mol} \%$, i.e. $\mathrm{P}\left(\mathrm{H}_{2} \mathrm{O}\right)=$ $0.12 \mathrm{~atm}){ }^{41}$ are shown.

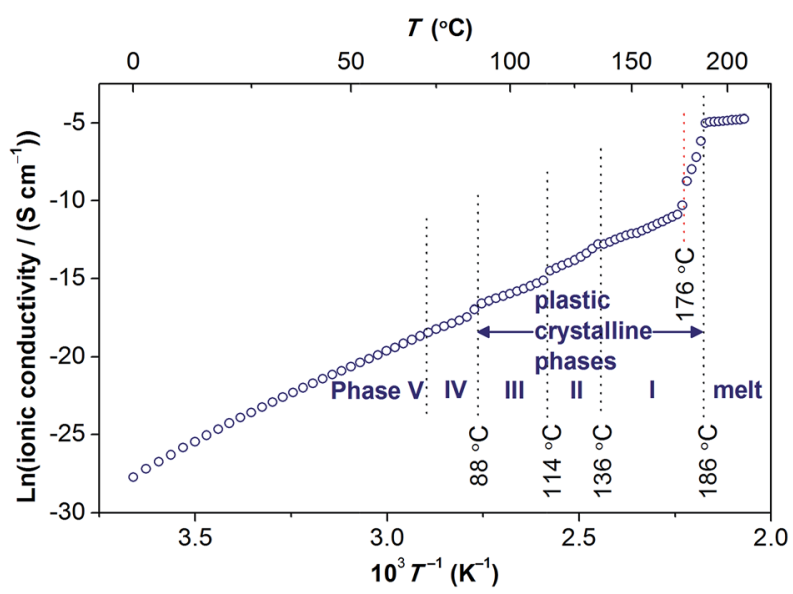

Fig. 11 Arrhenius plot for the ionic conductivity of [Gdm-H][NfO].

[NfO] is given in Fig. 11. The activation energy for each phase is calculated using the Arrhenius equation:

$$
\sigma=\sigma_{0} \exp \left(-\frac{E_{\mathrm{a}}}{R T}\right)
$$

where $\sigma$ is the ionic conductivity in $\mathrm{S} \mathrm{cm}^{-1}, \sigma_{0}$ the pre-exponential factor in $\mathrm{S} \mathrm{cm}^{-1}$ (i.e. the maximum ionic conductivity
Table 2 Fitting parameters for the ionic conductivity in each linear region using the Arrhenius equation

\begin{tabular}{lllll}
\hline Phase & $T /{ }^{\circ} \mathrm{C}$ & $E_{\mathrm{a}} / \mathrm{kJ} \mathrm{mol}^{-1}$ & $\sigma_{0} / \mathrm{S} \mathrm{cm}^{-1}$ & $R^{2 a}$ \\
\hline V \& IV & $0-85$ & $96.5(1.00 \mathrm{eV})$ & $1.01 \times 10^{6}$ & 0.9972 \\
III & $90-112.5$ & $75.2(0.780 \mathrm{eV})$ & $4.02 \times 10^{3}$ & 0.9961 \\
II & $115-135$ & $110.9(1.15 \mathrm{eV})$ & $3.87 \times 10^{8}$ & 0.9808 \\
I $^{b}$ & $137.5-172.5$ & $80.9(0.839 \mathrm{eV})$ & $5.39 \times 10^{4}$ & 0.9915 \\
Melt & $187.5-210$ & $19.1(0.198 \mathrm{eV})$ & 1.01 & 0.9814 \\
${ }^{a} R^{2}$ : correlation coefficient. ${ }^{b}$ Gradual change region of phase I.
\end{tabular}

that it would have at infinite temperature), and $E_{\mathrm{a}}$ the activation energy in $\mathrm{kJ} \mathrm{mol}^{-1}$. ${ }^{\mathrm{a} a}$

The fitting results are listed in Table 2. Overall, $E_{\mathrm{a}}$ decreases when $[\mathrm{Gdm}-\mathrm{H}][\mathrm{NfO}]$ is heated through each phase transition, which is in line with the same trend observed in 1,2,4-triazolium nonaflate, ${ }^{5 a}$ imidazolium methanesulfonate ${ }^{11 a}$ and some aprotic OIPCs, ${ }^{30 b, 42}$ reflecting the phase-dependent transport properties of [Gdm- $\mathrm{H}][\mathrm{NfO}]$. In phase $\mathrm{V}$ and $\mathrm{IV}$, [Gdm- $\mathrm{H}]$ [NfO] has a low ionic conductivity ranging from $1 \times$ $10^{-12} \mathrm{~S} \mathrm{~cm}^{-1}$ to $2.6 \times 10^{-8} \mathrm{~S} \mathrm{~cm}^{-1}$ and exhibiting a strong temperature dependence as the movement of ions is highly restricted in the relatively rigid lattice. Based on the high value of $E_{\mathrm{a}}\left(96.5 \mathrm{~kJ} \mathrm{~mol}^{-1}\right.$, i.e. $\left.1.00 \mathrm{eV}\right)$ and the low ionic conductivity, the mechanism for ion conduction in the ordered crystalline phase $\mathrm{V}$ is speculated to be lattice self-diffusion. ${ }^{8}$ As mentioned previously, after the solid-solid phase transitions happening at $88{ }^{\circ} \mathrm{C}, 114{ }^{\circ} \mathrm{C}$ and $136{ }^{\circ} \mathrm{C}$ successively, the ionic conductivity exceeds $6 \times 10^{-8} \mathrm{~S} \mathrm{~cm}^{-1}, 5 \times 10^{-7} \mathrm{~S} \mathrm{~cm}^{-1}$ and $2.8 \times$ $10^{-6} \mathrm{~S} \mathrm{~cm}^{-1}$, respectively, corresponding to the observed change of the crystalline structure of $[\mathrm{Gdm}-\mathrm{H}][\mathrm{NfO}]$ with the ions becoming more and more disordered (Fig. 9). Higher ionic conductivities in more disordered phases are considered to be associated with the ionic axial rotation and self-diffusion..$^{43}$

Furthermore, the Grotthuss mechanism (proton hopping or structural diffusion) and the vehicle mechanism are the two main mechanisms used in the literature for interpreting the proton conduction in solid compounds. ${ }^{44}$ The transport of larger ionic species (with greater mass compared to $\mathrm{H}^{+}$) requires a larger energy contribution, and as such processes with $E_{\mathrm{a}}>$ $0.4 \mathrm{eV}$ generally refer to the vehicle mechanism. ${ }^{45}$ As the activation energies (Table 2) for the temperature dependence of ionic conductivity in phase III, phase II and phase I are $75.2 \mathrm{~kJ} \mathrm{~mol}^{-1}(0.780 \mathrm{eV}), 110.9 \mathrm{~kJ} \mathrm{~mol}^{-1}(1.15 \mathrm{eV})$ and $80.9 \mathrm{~kJ} \mathrm{~mol}^{-1}(0.839 \mathrm{eV})$, respectively, it is speculated that the vehicle mechanism is the underlying conduction mechanism in these plastic crystalline phases (Fig. 11). This speculation is in agreement with the NMR experimental results for guanidinium triflate where proton hopping was not observed in neat guanidinium triflate. ${ }^{12 a}$ As the guanidinium cation is smaller, has a high symmetry and has a smaller inertia momentum than the large nonaflate anion, it is very likely that mainly the guanidinium cations are orientationally or rotationally disordered in the plastic crystalline phases of $[\mathrm{Gdm}-\mathrm{H}][\mathrm{NfO}]$, resulting in great cationic motions to favor proton conduction. When the temperature further increases in phase I to above $173{ }^{\circ} \mathrm{C}$, 
a linear and steep increase of the ionic conductivity is observed between $176{ }^{\circ} \mathrm{C}$ and $186{ }^{\circ} \mathrm{C}$, which should be largely due to the onset of partial melting (Fig. S12 and S13 $\dagger$ ).

In the molten state, the activation energy for ion conduction is as low as $19.1 \mathrm{~kJ} \mathrm{~mol}^{-1}(0.198 \mathrm{eV})$. While the vehicle mechanism $^{46}$ is expected to contribute to the proton conduction in the molten state of $[\mathrm{Gdm}-\mathrm{H}][\mathrm{NfO}]$ with the guanidinium cation as a vehicle, ${ }^{11 a, 18 e}$ the Grotthuss mechanism (structural diffusion) is postulated to contribute to the proton conduction involving hydrogen bonds between the cation and the anion as the temperature dependence of ionic conductivity exhibits an Arrhenius behavior (Fig. 11). As firstly proposed by Angell et al. ${ }^{27}$ the proton conduction behavior of guanidinium salt melts may be influenced by a population of protons that have the freedom to move between cations via temporary occupation of sites on the anion (transient reformation of the original proton donor acid), or in a transient dianion $[\mathrm{XHX}]^{-}$. The transient dianion path, which should be of lower energy, can be represented by the following reaction sequence: ${ }^{27}$

$$
\begin{array}{r}
{\left[\mathrm{C}\left(\mathrm{NH}_{2}\right)_{3}\right]^{+}+2 \mathrm{X}^{-} \rightarrow \mathrm{NH}_{2} \mathrm{C}(=\mathrm{NH}) \mathrm{NH}_{2}+\left[\mathrm{XHX}^{-} \rightarrow\right.} \\
{\left[\mathrm{C}\left(\mathrm{NH}_{2}\right)_{3}\right]^{+}+2 \mathrm{X}^{-}}
\end{array}
$$

where $\mathrm{X}$ denotes the nonaflate anion $\left[n-\mathrm{C}_{4} \mathrm{~F}_{9} \mathrm{SO}_{3}\right]^{-}$. The intermediate energy sites of the dianions, which may arise via fluctuations in the molecule ion coordinates in the natural course of thermal motions can be taken advantage of with much higher probability because the guanidinium cation presents six equally probably "launch points" for its protons rather than only a single exchangeable proton per cation. ${ }^{27}$ In fact, the nearly complete deuteration of guanidinium cations $\left(\left[\mathrm{C}\left(\mathrm{NH}_{2}\right)_{3}\right]^{+}\right)$with $\mathrm{D}_{2} \mathrm{O}$ (Fig. 2 and Fig. $\mathrm{S} 1 \dagger$ ) even at room temperature proves that in the liquidus state each guanidinium cation has six displaceable protons.

\section{Conclusions}

Protic organic ionic plastic crystals (POIPCs) are promising solid-state proton conductors. As a special mesophase, their isotropy happens before their transition into a molten state. With guanidinium nonaflate $([\mathrm{Gdm}-\mathrm{H}][\mathrm{NfO}])$ as an example, we show that solid-state proton conductors based on POIPCs can be achieved via appropriate molecular design involving symmetrical ions. Differential scanning calorimetry and variable-temperature powder X-ray diffraction measurements together reveal the presence of plastic crystalline phases in the temperature range between $88^{\circ} \mathrm{C}$ and $185{ }^{\circ} \mathrm{C}$. As expected, $[\mathrm{Gdm}-\mathrm{H}][\mathrm{NfO}]$ exhibits a short-range disorder and a long-range positional order in the plastic crystalline phases. Above $176^{\circ} \mathrm{C}$, the ionic conductivity of [Gdm-H][NfO] exceeds $1 \times 10^{-4} \mathrm{~S} \mathrm{~cm}^{-1}$ prior to its melting point at $186.2{ }^{\circ} \mathrm{C}$. In the high temperature plastic crystalline phase, the elegant symmetrical guanidinium cations of $[\mathrm{Gdm}-\mathrm{H}][\mathrm{NfO}]$ seem to rotate freely, leading to a simpler crystal structure of higher symmetry and fast ion conduction. The vehicle mechanism is assumed to be the underlying conduction mechanism in the plastic crystalline phases of $[\mathrm{Gdm}-\mathrm{H}][\mathrm{NfO}]$. In the molten state, the proton conduction is proposed to occur via both the vehicle mechanism and the Grotthuss mechanism (structural diffusion). Due to the exceptional physicochemical properties such as high thermal stability, negligible volatility, non-flammability, no leakage, high electrochemical stability, high anhydrous proton conductivity, and wide plastic crystalline phases, POIPCs like [Gdm-H][NfO] are attractive electrolytes for high temperature (100-200 ${ }^{\circ} \mathrm{C}$ ) proton exchange membrane fuel cells (PEMFCs), in particular, all-solid-state high temperature PEMFCs. In addition to its role as a dopant to replace $\mathrm{H}_{3} \mathrm{PO}_{4}$ for state-of-theart membrane matrices, [Gdm- $\mathrm{H}][\mathrm{NfO}]$ may also function as a solid-state matrix for acids to develop more conductive proton conductors. It is anticipated that POIPC-based fast solid-state proton conductors will also find applications in sensors and other electrochemical devices. Further work on [Gdm- $][\mathrm{NfO}]$ (e.g. demonstration in practical fuel cells) is in progress in our labs. It is noteworthy that poly(ionic liquid)s offer promising membrane matrices for solid-state proton conductors. ${ }^{47}$

\section{Acknowledgements}

J. L. acknowledges the Research Foundation - Flanders (FWO) for a Postdoctoral Fellowship (12F5514N), a Research Grant (Project number: $1529816 \mathrm{~N}$ ) and a travel grant (V410316N) for a Visiting Professorship in the Technical University of Denmark. This work is financially supported by the National Natural Science Foundation of China (No. 51472187, 51272200). Financial support from China Fund KU Leuven (ISP/13/02SJT) is acknowledged. We would like to thank Dr Qing-An Chen (Technische Universität Berlin) for technical discussions on NMR. J. L. appreciates comments from Prof. Dr Douglas R. MacFarlane (Monash University) and Dr Olaf Conrad (SCHMID Energy Systems, Germany).

\section{Notes and references}

1 (a) B. Yi, Fuel Cells-Principle, Technology and Application, Chemical Industry Press, Beijing, 2003; (b) H. A. Gasteiger and N. M. Marković, Science, 2009, 324, 48; (c) M. K. Debe, Nature, 2012, 486, 43; (d) H. Tang, Y. Zeng, D. Liu, D. Qu, J. Luo, K. Binnemans, D. E. De Vos, J. Fransaer, D. Qu and S.-G. Sun, Nano Energy, 2016, 26, 131.

2 (a) J. Zhang, Z. Xie, J. Zhang, Y. Tang, C. Song, T. Navessin, Z. Shi, D. Song, H. Wang, D. P. Wilkinson, Z. Liu and S. Holdcroft, J. Power Sources, 2006, 160, 872; (b) Q. Li, J. O. Jensen, R. F. Savinell and N. J. Bjerrum, Prog. Polym. Sci., 2009, 34, 449; (c) A. Chandan, M. Hattenberger, A. Elkharouf, S. Du, A. Dhir, V. Self, B. G. Pollet, A. Ingram and W. Bujalski, J. Power Sources, 2013, 231, 264.

3 J. S. Wainright, J.-T. Wang, D. Weng, R. F. Savinell and M. Litt, J. Electrochem. Soc., 1995, 142, L121.

4 (a) S.-Y. Lee, A. Ogawa, M. Kanno, H. Nakamoto, T. Yasuda and M. Watanabe, J. Am. Chem. Soc., 2010, 132, 9764; (b) J. S. Lee, T. Nohira and R. Hagiwara, J. Power Sources, 2007, 171, 535; (c) F. Endres and S. Z. E. Abedin, Phys. Chem. Chem. Phys., 2006, 8, 2101; (d) M. Armand, F. Endres, 
D. R. MacFarlane, H. Ohno and B. Scrosati, Nat. Mater., 2009, 8, 621 .

5 (a) J. Luo, A. H. Jensen, N. R. Brooks, J. Sniekers, M. Knipper, D. Aili, Q. Li, B. Vanroy, M. Wübbenhorst, F. Yan, L. Van Meervelt, Z. Shao, J. Fang, Z.-H. Luo, D. E. De Vos, K. Binnemans and J. Fransaer, Energy Environ. Sci., 2015, 8, 1276; (b) S. M. Haile, D. A. Boysen, C. R. I. Chisholm and R. B. Merle, Nature, 2001, 410, 910; (c) D. A. Boysen, T. Uda, C. R. I. Chisholm and S. M. Haile, Science, 2004, 303, 68; (d) J. A. Hurd, R. Vaidhyanathan, V. Thangadurai, C. I. Ratcliffe, I. L. Moudrakovski and G. K. H. Shimizu, Nat. Chem., 2009, 1, 705.

6 (a) D. R. MacFarlane, J. H. Huang and M. Forsyth, Nature, 1999, 402, 792; (b) Y. Abu-Lebdeh, A. Abouimrane, P.-J. Alarco, A. Hammami, L. Ionescu-Vasii and M. Armand, Electrochem. Commun., 2004, 6, 432; (c) P.-J. Alarco, Y. Abu-Lebdeh, A. Abouimrane and M. Armand, Nat. Mater., 2004, 3, 476.

7 (a) V. Armel, M. Forsyth, D. R. MacFarlane and J. M. Pringle, Energy. Environ. Sci., 2011, 4, 2234; (b) M. Hattori, S. Fukada and D. Nakamura, J. Chem. Soc., Faraday Trans., 1990, 86, 3777; (c) W. A. Henderson, D. M. Seo, Q. Zhou, P. D. Boyle, J.-H. Shin, H. C. De Long, P. C. Trulove and S. Passerini, Adv. Energy Mater., 2012, 2, 1343.

8 D. R. MacFarlane and M. Forsyth, Adv. Mater., 2001, 13, 957. 9 J. M. Pringle, P. C. Howlett, D. R. MacFarlane and M. Forsyth, J. Mater. Chem., 2010, 20, 2056.

10 (a) U. A. Rana, R. Vijayaraghavan, D. R. MacFarlane and M. Forsyth, Chem. Commun., 2011, 47, 6401; (b) U. A. Rana, M. Forsyth, D. R. MacFarlane and J. M. Pringle, Electrochim. Acta, 2012, 84, 213.

11 (a) J. Luo, O. Conrad and I. F. J. Vankelecom, J. Mater. Chem. A, 2013, 1, 2238; (b) J. Luo, Ph.D. thesis, KU Leuven, 2012.

12 (a) H. Zhu, U. Rana, V. Ranganathan, L. Jin, L. A. O'Dell, D. R. MacFarlane and M. Forsyth, J. Mater. Chem. A, 2014, 2, 681; (b) H. Zhu, D. MacFarlane and M. Forsyth, J. Phys. Chem. C, 2014, 118, 28520.

13 (a) J. Leys, M. Wübbenhorst, C. P. Menon, R. Rajesh, J. Thoen, C. Glorieux, P. Nockemann, B. Thijs, K. Binnemans and S. Longuemart, J. Chem. Phys., 2008, 128, 064509; (b) J. R. Sangoro, A. Serghei, S. Naumov, P. Galvosas, J. Kaerger, C. Wespe, F. Bordusa and F. Kremer, Phys. Rev. E: Stat., Nonlinear, Soft Matter Phys., 2008, 77, 051201.

14 C. L. Angell, N. Sheppard, A. Yamaguchi, T. Shimanouchi, T. Miyazawa and S. Mizushima, Trans. Faraday Soc., 1957, 53, 589.

15 L. Pauling, Nature of the Chemical Bond, Cornell University Press, 1942, p. 213.

16 R. J. Sension, B. Hudson and P. R. Callis, J. Phys. Chem., 1990, 94, 4015.

17 M. Drozd, Mater. Sci. Eng., B, 2007, 136, 20.

18 (a) J. Luo, O. Conrad and I. F. J. Vankelecom, J. Mater. Chem., 2012, 22, 20574; (b) J. Luo, J. Hu, W. Saak, R. Beckhaus, G. Wittstock, I. F. J. Vankelecom, C. Agert and O. Conrad, J. Mater. Chem., 2011, 21, 10426; (c) E. S. Stoyanov, K.-C. Kim and C. A. Reed, J. Am. Chem. Soc., 2006, 128,
8500; (d) K. Mori, S. Hashimoto, T. Yuzuri and K. Sakakibara, Bull. Chem. Soc. Jpn., 2010, 83, 328; (e) J. Luo, T. V. Tan, O. Conrad and I. F. J. Vankelecom, Phys. Chem. Chem. Phys., 2012, 14, 11441.

19 A. Bernson and J. Lindgren, Solid State Ionics, 1993, 60, 37.

20 R. Langner and G. Zundel, J. Chem. Soc., Faraday Trans., 1998, 94, 1805.

21 Online edition for students of organic chemistry lab courses at the University of Colorado, Boulder, Dept. of Chem. and Biochem., Chapter 15, Infrared Spectroscopy: Theory (2002). http://orgchem.colorado.edu/Spectroscopy/irtutor/ IRtheory.pdf.

22 (a) K. D. Kreuer, A. Fuchs, M. Ise, M. Spaeth and J. Maier, Electrochim. Acta, 1998, 43, 1281; (b) S. Li, Z. Zhou, Y. Zhang, M. Liu and W. Li, Chem. Mater., 2005, 17, 5884.

23 Y. Huang, Q. Li, A. H. Jensen, M. Yin, J. O. Jensen, E. Christensen, C. Pan, N. J. Bjerrum and W. Xing, J. Mater. Chem., 2012, 22, 22452.

24 H. Luo, G. A. Baker and S. Dai, J. Phys. Chem. B, 2008, 112, 10077.

25 H. Luo, G. A. Baker, J. S. Lee, R. M. Pagni and S. Dai, J. Phys. Chem. B, 2009, 113, 4181.

26 D. R. MacFarlane, J. M. Pringle, K. M. Johansson, S. A. Forsyth and M. Forsyth, Chem. Commun., 2006, 1905.

27 Z. Zhao, K. Ueno and C. A. Angell, J. Phys. Chem. B, 2011, 115, 13467.

28 M. Yoshizawa, W. Xu and C. A. Angell, J. Am. Chem. Soc., 2003, 125, 15411.

29 S. A. Forsyth, K. J. Fraser, P. C. Howlett, D. R. MacFarlane and M. Forsyth, Green Chem., 2006, 8, 256.

30 (a) J. Sun, D. R. MacFarlane and M. Forsyth, Solid State Ionics, 2002, 148, 145; (b) R. Asayama, J. Kawamura and T. Hattori, Chem. Phys. Lett., 2005, 414, 87; (c) V. Armel, D. Velayutham, J. Sun, P. C. Howlett, M. Forsyth, D. R. MacFarlane and J. M. Pringle, J. Mater. Chem., 2011, 21, 7640 .

31 J. Timmermans, J. Phys. Chem. Solids, 1961, 18, 1.

32 (a) K. Kuchitsu, H. Ono, S. Ishimaru, R. Ikeda and H. Ishida, Phys. Chem. Chem. Phys., 2000, 2, 3883; (b) N. G. Parsonage and L. A. K. Staveley, Disorder in Crystals, Clarendon Press, Oxford, 1978.

33 P. Jain, V. Ramachandran, R. J. Clark, H. D. Zhou, B. H. Toby, N. S. Dalal, H. W. Kroto and A. K. Cheetham, J. Am. Chem. Soc., 2009, 131, 13625.

34 Y. Tang, Z. Sun, C. Ji, L. Li, S. Zhang, T. Chen and J. Luo, Cryst. Growth Des., 2015, 15, 457.

35 S. Hoshino, T. Mitsui, F. Jona and R. Pepinsky, Phys. Rev., 1957, 107, 1255.

36 (a) W. A. Henderson, V. G. Young Jr, W. Pearson, S. Passerini, H. C. De Long and P. C. Trulove, J. Phys.: Condens. Matter, 2006, 18, 10377; (b) F. Meersman, B. Geukens, M. Wübbenhorst, J. Leys, S. Napolitano, Y. Filinchuk, G. Van Assche, B. Van Mele and E. Nies, J. Phys. Chem. B, 2010, 114, 13944.

37 U. A. Rana, R. Vijayaraghavan, C. M. Doherty, A. Chandra, J. Efthimiadis, A. J. Hill, D. R. MacFarlane and M. Forsyth, J. Phys. Chem. C, 2013, 117, 5532. 
38 G. Xu, K. Otsubo, T. Yamada, S. Sakaida and H. Kitagawa, J. Am. Chem. Soc., 2013, 135, 7438.

39 U. A. Rana, R. Vijayaraghavan, D. R. MacFarlane and M. Forsyth, Chem. Commun., 2011, 47, 6401.

40 Y. Abu-Lebdeh, A. Abouimrane, P.-J. Alarco, A. Hammami, L. Ionescu-Vasii and M. Armand, Electrochem. Commun., 2004, 6, 432.

41 A. H. Jensen, Q. Li, E. Christensen and N. J. Bjerrum, J. Electrochem. Soc., 2014, 161, F72.

42 L. Jin, K. M. Nairn, C. M. Forsyth, A. J. Seeber, D. R. MacFarlane, P. C. Howlett, M. Forsyth and J. M. Pringle, J. Am. Chem. Soc., 2012, 134, 9688.
43 T. Shimizu, S. Tanaka, N. Onoda-Yamamuro, S. Ishimaru and R. Ikeda, J. Chem. Soc., Faraday Trans., 1997, 93, 321.

44 K.-D. Kreuer, Chem. Mater., 1996, 8, 610.

45 P. Ramaswamy, N. E. Wong and G. K. H. Shimizu, Chem. Soc. Rev., 2014, 43, 5913.

46 K.-D. Kreuer, A. Rabenau and W. Weppner, Angew. Chem., Int. Ed. Engl., 1982, 21, 208.

47 (a) P. Wang, Y.-N. Zhou, J.-S. Luo and Z.-H. Luo, Polym. Chem., 2014, 5, 882; (b) H. Cheng, P. Wang, J. Luo, J. Fransaer, D. E. De Vos and Z.-H. Luo, Ind. Eng. Chem. Res., 2015, 54, 3107; (c) F. Lu, X. Gao, P. Sun and L. Zheng, New J. Chem, 2016, DOI: 10.1039/c6nj01284a. 